\title{
Physico-chemical processes in a vadose zone during the infiltration of treated wastewater used for irrigation: application of the NETPATH model
}

\author{
M.V. Esteller · I. Morell · C. Almeida
}

Abstract Irrigation with treated wastewater was carried out in an experimental site in Castellon (eastern part of Spain). By using water soil samplers at different depths some physico-chemical parameters (conductivity, $\mathrm{pH}$, major ions, nitrogen species, BOD, COD, and organic matter) were controlled to identify the processes affecting the self-cleaning power of the vadose zone. Modeling of these processes has been carried out by means of the NETPATH software. Two intervals have been considered, the first one from 15 to $180 \mathrm{~cm}$ in depth and the second one from 180 to $240 \mathrm{~cm}$, in which ionic exchange processes affecting $\mathrm{Na}^{+}, \mathrm{Ca}^{2+}, \mathrm{Mg}^{2+}$, and $\mathrm{K}^{+}$, calcite precipitation, and dolomite and gypsum dissolution are active. The main differences between the intervals are modifications of $\mathrm{CO}_{2}$ interchange and the behavior of sodium. As a result of the synergic effect of different processes involved there is a good level of purification.

Keywords Wastewater - Irrigation - Vadose zone Pollution $\cdot$ Modeling

Received: 22 August 2000 / Accepted: 4 December 2000 Published online: 22 March 2001

(C) Springer-Verlag 2001

M.V. Esteller ( $\square)$

Interamerican Center for Water Resources,

Faculty of Engineering, Universidad Autonoma del Estado de Mexico, Cerro Coatepec, S/N C.U., 50130 Toluca, Mexico

E-mail: esteller@coatepec.uaemex.mx

Tel.: +52-729-65550

Fax: +52-729-65551

I. Morell

Department of Experimental Sciences, Universidad Jaume I. P.0. Box 224, 12071 Castellon, Spain

C. Almeida

Department of Geology, Faculty of Sciences,

University of Lisbon, Campo Grande, 1700 Lisbon, Portugal

\section{Introduction}

Research relevant to the behavior of polluting substances during migration through a vadose zone has, in the past few years, made noticeable progress. Many projects developed in the laboratory, through batch or column experiments, tending to simulate processes of pesticide adsorption (Gómez and others 1993; Beltran and others 1995; Gerritse and others 1996; Moreau and Mouvet 1997), heavy metal sorption (Flores and others 1997; Ramachandran and D'Souza 1997), infiltration of saline waters (Appelo and others 1990), and wastewater purification (Salgot and Pascual 1991), have been developed. In the laboratory it is difficult to faithfully reproduce field conditions, both environmental as well as lithological and hydrodynamic, and this suggests that these types of studies should be approached from the experimental sites on which the substance to be studied has been applied. With appropriate techniques of sampling of soils and/or soil water (Boulding 1995; Wilson and others 1995) the migration may be controlled in a real context, where the characteristics must be known. Examples of this type of field study on leaching of pesticides can be found in Beltran and others (1993) and Azevedo and others (1997); on the transport of nitrates in Jemison and Fox (1994), Jabro and others (1995), and Morell and others (1996); and studies on purification of wastewater through vadose zone in Bustamante (1990), Tedaldi and Loehr (1992), Esteller and others (1994), and Shahalam and others (1998). In arid or semiarid countries it is becoming more and more common to use urban wastewater for irrigation, and this is not always subjected to even a primary purification process prior to being used. In reality, the application of treated wastewater on the land presupposes one additional purification treatment of the water since, when the water filtrates through a vadose zone, numerous physical, chemical, and biological processes occur, which cause a decrease in the polluting factor.

Establishing the importance of each of the processes considered or trying to quantify them presents a certain degree of difficulty as many of these processes may interact, and, in addition, different processes may give rise to similar results. To help solve this situation it is 
very useful to apply hydrogeochemical models to determine which processes and reactions have taken place, as well as the scope of these reactions. Most of the models identify and quantify the elements which intervene in the equilibrium reactions based on the states of saturation (states of equilibrium) of water with reference to different phases (minerals, gases, organic compounds, etc.). This allows one to establish precipitation and/or dissolution tendencies at the same time. Some models also carry out calculation of mass balance in order to determine the amounts of reactives and products of the reaction that dissolve or are precipitated between an initial point and another final point, both being situated along the same flow line. This type of model is called an inverse model.

In general, hydrogeochemical models have been applied in the research on groundwater with the purpose of establishing and quantifying which types of chemical modifications are produced in the water of the aquifer. In the research presented here these models have been applied to the study of soil water, as the bases upon which the hydrogeochemical modeling are founded can be extrapolated to this field.

There are numerous models available, both speciation as well as inverse, that allow for these hydrogeochemical studies. Among these is NETPATH (Plummer and others 1991), which enables the calculation of the distribution of different species in solution, molal concentrations, and the activities of each one of the ions and ionic pairs, as well as the saturation indices. In addition, it allows for definition and quantification along a flow line of the chemical reactions and the mass transferences.
The purpose of this paper is to investigate the applicability of this model in the study of reactions presented during infiltration through a vadose zone of wastewater used for irrigation, to quantify the processes that are involved in the purification treatment of this water.

\section{Experimental}

\section{Experimental site}

To study the physical, chemical, and biological processes that take place during infiltration of treated wastewater used for irrigation through a vadose zone an experimental site was adapted in the unconsolidated aquifer of Plana de Castellon located on the east coast of Spain (Fig. 1). This experimental site was equipped with porous ceramic suction cup samplers installed along the vadose zone at depths of $15,30,60,120,180$, and $240 \mathrm{~cm}$. The groundwater level was located at $290 \mathrm{~cm}$, with seasonal variations of a maximum of $10 \mathrm{~cm}$.

The irrigation with treated wastewater was carried out following the normal guidelines of local agriculture, that is, an irrigation dose of $8000 \mathrm{~m}^{3} / \mathrm{ha} /$ year and a periodic irrigation every 20 days, with some variations depending on the climatic conditions. The experiment was carried out between the months of June 1992 and September 1993. The soil water samples were collected 3 days after irrigation through the application of a vacuum in the interior of the capsules with a pressure of 60 cbar.

The samples of treated wastewater used for irrigation and the samples of soil water were collected in polyethylene

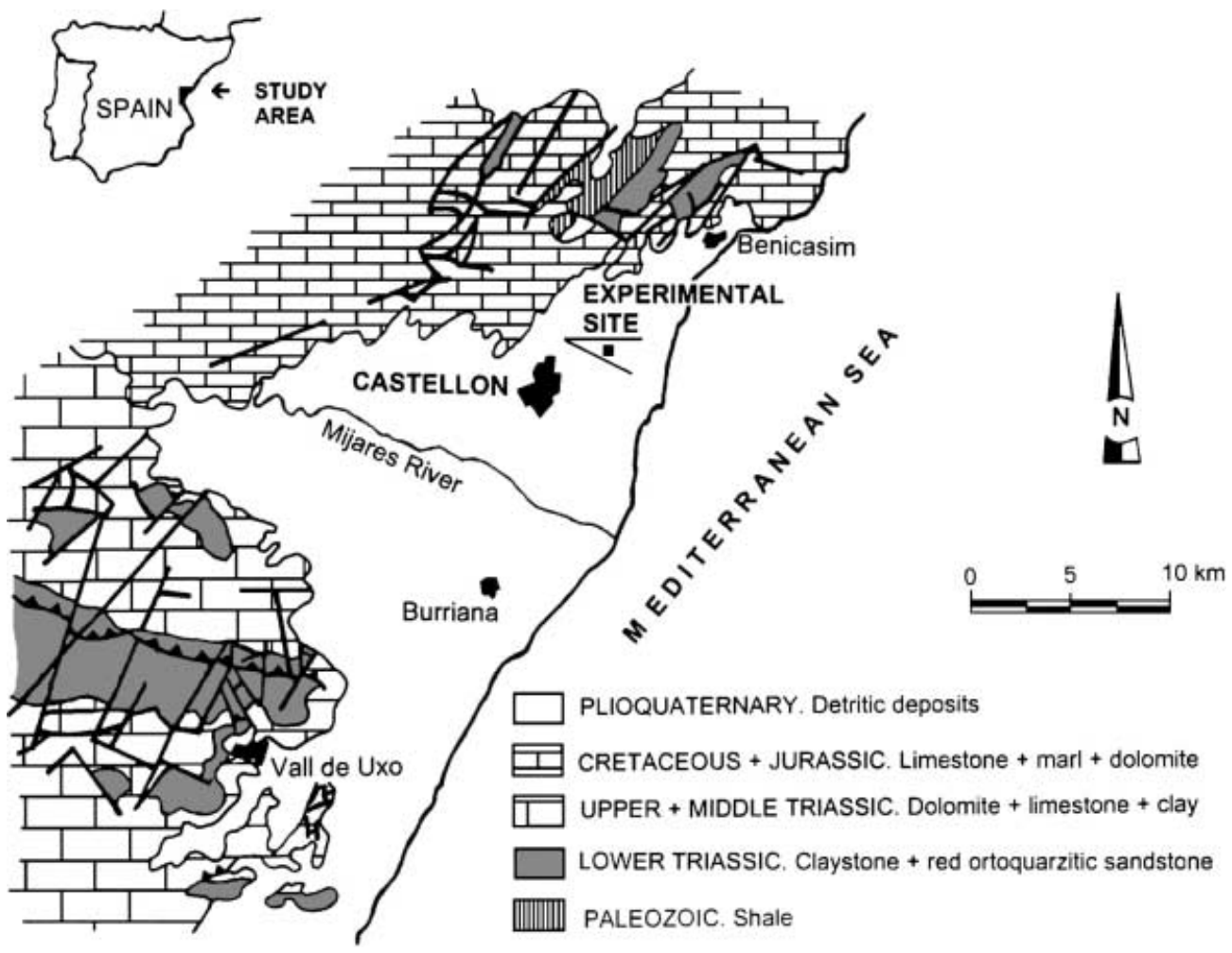

Fig. 1

Location of experimental site in Plana de Castellon aquifer (Spain), showing geological outline of the aquifer and its surroundings 
bottles and stored in refrigeration at $4{ }^{\circ} \mathrm{C}$ until the time of analysis which, in every case, took place within a lapse of no more than 3 days. The parameters analyzed were conductivity, $\mathrm{pH}$, bicarbonates, chlorides, sulfates, nitrates, nitrites, ammonium, phosphates, calcium, magnesium, sodium, boron, chemical oxygen demand (COD), biochemical oxygen demand $\left(\mathrm{BOD}_{5}\right)$, and organic matter. Analyses were carried out according to standard methods (APHA AWWA WPCF 1995) except for BOD (Clark 1959) and boron (López and others 1993).

To characterize the vadose zone, several tests were carried out through manual perforation with an Edelman helicoidal auger. In the laboratory, texture, content of organic matter, and $\mathrm{pH}$ were determined for the samples obtained. The clay fraction was analyzed by X-ray diffraction.

\section{NETPATH model description}

The NETPATH software (Plummer and others 1991) includes several programs: DB, WATEQF, and NETPATH. The DB program is an interactive program that allows for storage of chemical analysis data, to be used later in the WATEQF program.

The WATEQF program (Truesdell and Jones 1974; Plummer and others 1984) is capable of calculating the distribution of different species in solution, defining molalities and activities of each of the ions and the ion pairs that may be formed. It also calculates the saturation indices of all the phases defined based on the input of analytical data. The results obtained are later used by NETPATH.

The NETPATH model is a program designed to define and quantify chemical reactions consistent with the initial chemical data along a flow line (this set of reactions will define the reactive models). To be used it requires the chemical composition of two points situated on the same flow line and the chemical composition of the set of minerals, gases, or organic compounds that represent the reactants or products of the reaction. The program calculates the mass transference (amounts of the phases entering or leaving the dissolution along the flow line) needed to justify the chemical changes observed between the two points.

\section{Results and discussion}

\section{Vadose zone characterization}

A textural analysis was carried out, obtaining from the different samples the results shown in Table 1. In the first $90 \mathrm{~cm}$, a first level is defined where the finest fraction is present in a high percentage, later gradually decreasing with depth to reach very low percentages. After the $180 \mathrm{~cm}$ mark the silt plus sand fraction predominates with percentages above $90 \%$. Between these two levels, another level can be defined, covering depths between 120 and $180 \mathrm{~cm}$, with a particle size distribution in which the clay fraction is present at a percentage of around $20 \%$ and the thickest fraction with percentages of $80 \%$.

A determination of the organic matter and $\mathrm{pH}$ in these same samples was also carried out. Based on the content of the organic matter, the sample closest to the surface $(15 \mathrm{~cm})$ represents soil suitable for crops, whereas the samples collected at a depth of $30 \mathrm{~cm}$ represent poor soil. The rest of the samples are catalogued as very poor (Table 1).

To find out more exactly the mineralogical composition of the clays present in the vadose zone these have been analyzed using the X-ray diffraction technique, with which an identification as well as an approximate quantification (in percentages) of the type of existing clay can be obtained (Table 1). The most abundant clays, in all of the samples, are those of illite type, finding a maximum of $83 \%$ at a depth of $60 \mathrm{~cm}$ and a minimum of $68 \%$ at the topmost level $(30 \mathrm{~cm})$. This is followed in abundance by smectite, whose presence is quantified around $15 \%$, with a maximum value of $23 \%$ in the sample taken at a depth of $30 \mathrm{~cm}$. The least abundant clays are those of the kaolinite type, with percentages which vary between 2 and $9 \%$.

\section{Leaching experiment}

All of the controlled pollutants along the profile of the vadose zone, except nitrates, undergo an important decrease in concentration as they infiltrate through the vadose zone, due to the effects of the physical, chemical, and biological processes which take place (Esteller and Morell 1993). This decrease in the polluting charge of the percolated water, as well as the variations in concentrations which the other physico-chemical parameters undergo,

Table 1

Selected physico-chemical characteristics of the vadose zone. O.M. Organic matter

\begin{tabular}{|c|c|c|c|c|c|c|c|c|}
\hline $\begin{array}{l}\text { Depth } \\
(\mathrm{cm})\end{array}$ & $\begin{array}{l}\text { Clay } \\
(\%)\end{array}$ & $\begin{array}{l}\text { Silt } \\
(\%)\end{array}$ & $\begin{array}{l}\text { Sand } \\
(\%)\end{array}$ & $\begin{array}{l}\text { O.M. } \\
(\%)\end{array}$ & $\mathrm{pH}$ & $\begin{array}{l}\text { Illite } \\
(\%)\end{array}$ & $\begin{array}{l}\text { Smectite } \\
(\%)\end{array}$ & $\begin{array}{l}\text { Kaolinite } \\
(\%)\end{array}$ \\
\hline 15 & 24 & 26 & 50 & 1.61 & 7.62 & - & - & - \\
\hline 30 & 22 & 33 & 45 & 1.33 & - & 68 & 23 & 9 \\
\hline 60 & 27 & 21 & 52 & 0.74 & - & 83 & 15 & 2 \\
\hline 90 & 30 & 16 & 54 & 0.70 & 7.45 & 79 & 14 & 7 \\
\hline 120 & 18 & 33 & 49 & 0.60 & - & - & - & - \\
\hline 150 & 20 & 36 & 44 & 0.56 & - & 76 & 15 & 9 \\
\hline 180 & 2 & 32 & 65 & 0.40 & - & - & - & - \\
\hline 220 & 2 & 49 & 49 & 0.07 & - & 78 & 15 & 7 \\
\hline 260 & 7 & 37 & 56 & 0.03 & - & - & - & - \\
\hline
\end{tabular}


Table 2

Physico-chemical characteristics of treated wastewater and soil water at $240 \mathrm{~cm}$ depth (mean values)

\begin{tabular}{|c|c|c|c|c|}
\hline Parameter & Units & $\begin{array}{l}\text { Treated } \\
\text { wastewater }\end{array}$ & $\begin{array}{l}\text { Soil water } \\
\text { at depth } \\
\text { of } 240 \mathrm{~cm}\end{array}$ & Percentage \\
\hline $\mathrm{pH}$ & & 7.76 & 7.80 & +0.5 \\
\hline Conductivity & $\mu \mathrm{S} / \mathrm{cm}$ & 1678 & 2347 & +40 \\
\hline $\mathrm{HCO}_{3}^{-}$ & mg/l & 434 & 336 & -26 \\
\hline $\mathrm{Cl}^{-}$ & $\mathrm{mg} / \mathrm{l}$ & 205 & 215 & +5 \\
\hline $\mathrm{NO}_{3}^{-}$ & $\mathrm{mg} / \mathrm{l}$ & 11 & 144 & +1209 \\
\hline $\mathrm{SO}_{4}^{2-}$ & $\mathrm{mg} / 1$ & 230 & 637 & +176 \\
\hline $\mathrm{Mg}^{2+}$ & $\mathrm{mg} / \mathrm{l}$ & 33 & 52 & +57 \\
\hline $\mathrm{Na}^{+}$ & $\mathrm{mg} / 1$ & 165 & 170 & +3 \\
\hline $\mathrm{Ca}^{2+}$ & $\mathrm{mg} / \mathrm{l}$ & 125 & 327 & +162 \\
\hline $\mathrm{K}^{+}$ & $\mathrm{mg} / \mathrm{l}$ & 15 & 2 & -87 \\
\hline $\mathrm{NH}_{4}^{+}$ & $\mathrm{mg} / \mathrm{l}$ & 4.8 & 0.1 & -98 \\
\hline $\mathrm{NO}_{2}^{-}$ & $\mathrm{mg} / \mathrm{l}$ & 0.24 & 0.15 & -63 \\
\hline Organic matter & $\mathrm{mg} / 1 \mathrm{O}_{2}$ & 35 & 21 & -40 \\
\hline Boron & $\mathrm{mg} / 1$ & 1.2 & 0.9 & -10 \\
\hline $\mathrm{PO}_{4}^{3-}$ & $\mathrm{mg} / 1$ & 10 & 0.2 & -98 \\
\hline $\mathrm{BOD}_{5}$ & $\mathrm{mg} / \mathrm{l} \mathrm{O}_{2}$ & 52 & 14 & -73 \\
\hline COD & $\mathrm{mg} / \mathrm{l} \mathrm{O}_{2}$ & 92 & 42 & -55 \\
\hline
\end{tabular}

may be seen in Table 2, which compares the characteristics of the treated wastewater used for irrigation with that of soil water collected in the sampler installed at a depth of $240 \mathrm{~cm}$ (mean values of the time studied). The variation in concentration with the depth (data in percentage) of each one of the controlled parameters is also quantified.

In general terms, it can be seen that the vadose zone acted as a filter eliminating organic compounds, which is reflected in a decrease in organic matter, $\mathrm{BOD}_{5}$, and $\mathrm{COD}$, basically as an effect of the biodegradation which affects the organic substances present in the treated wastewater. This process takes place in the top layers of soil where the available oxygen, as well as the microbial activity, is very high. Other processes which may contribute to these decreases are the adsorption of organic particles present in the soil and volatilization.

It was also seen from graphs of the evolution of $\mathrm{BOD}_{5}$, COD, and organic matter along the profile of the vadose zone (Fig. 2) that there were maximum values at a depth of $60 \mathrm{~cm}$. This seems to be linked to the presence of relatively anaerobic conditions. The texture at this level is very fine, which makes the entrance of air difficult, and, at the same time, facilitates the maintenance of a high degree of saturation for long periods of time. It has also been proven that there is a slight increase at a depth between 180 and $240 \mathrm{~cm}$, which might be related to the elevated saturation of the pores at this depth, since the groundwater level is found very close by.

The different processes and transformations that affect the behavior of nitrogen in all of its forms deserve special mention. The nitrification of ammonium and nitrites and the mineralization and later nitrification of organic nitrogen has been proven. Other modifying processes, which may be present since conditions seem to be favorable, are volatilization of ammonium and a certain amount of denitrification.
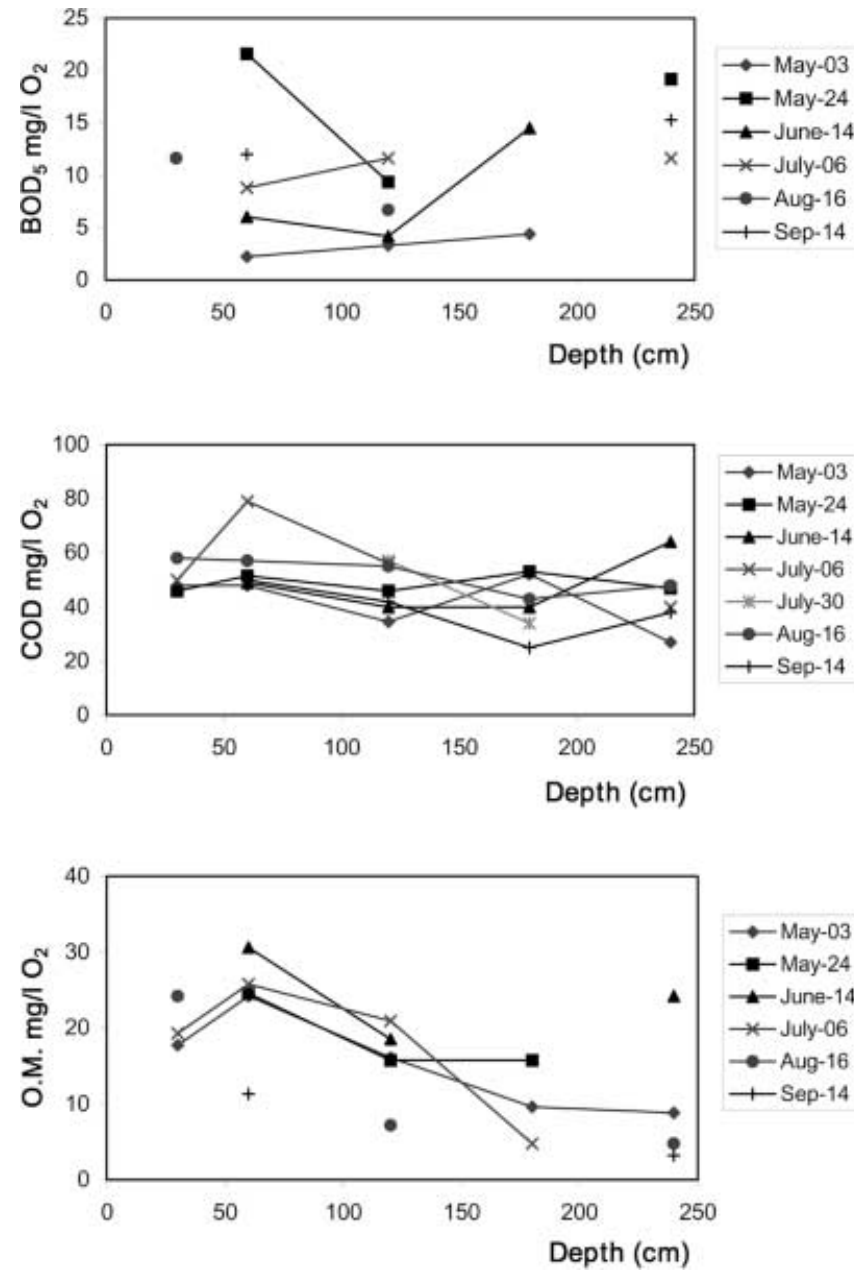

Fig. 2

Temporal evolution of $\mathrm{BOD}_{5}, \mathrm{COD}$, and organic matter in vadose zone

Leaching of nitrates (Fig. 3) can also demonstrated. At the outset of the experiment, leaching of this ion, present in the vadose zone because of previous fertilization, was seen. This produces a drag throughout the profile of the vadose zone, since irrigation with treated wastewater does not imply large amounts of nitrates. Months after irrigation was started some nitrogenated fertilizers were applied, which caused an important input of nitrates. After this application, progress in nitrates, with concentrations above $500 \mathrm{mg} / \mathrm{l}$, was seen throughout the vadose zone. A similar leaching process was seen, although not as intensely, affecting the sulfates. The application of fertilizers also implies contributions of sulfates which, later, due to the effects of irrigation, leach.

Cations are affected, among other processes, by ionic exchange, mainly between calcium and ammonium, in the first centimeters of the profile, and between potassium or sodium and calcium or magnesium. The important decrease in the concentration of potassium in the first few centimeters of the vadose zone due mainly to this exchange process should be highlighted (Fig. 4). The clay minerals and organic matter present have a high exchange 

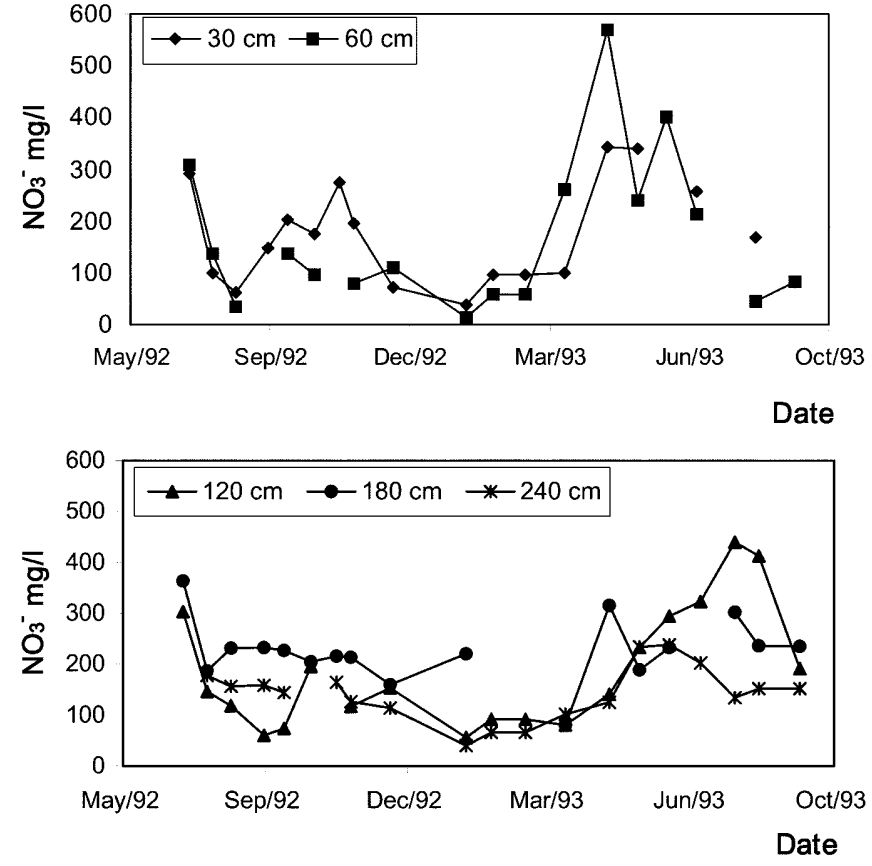

Fig. 3

Temporal evolution of the nitrate concentrations in the vadose zone

capacity, with the smectite having a capacity which varies between 80 and $150 \mathrm{meq} / 100 \mathrm{~g}$, the illite between 10 and $40 \mathrm{meq} / 100 \mathrm{~g}$, the kaolinite between 3 and $15 \mathrm{meq} / 100 \mathrm{~g}$, and the organic matter between 150 and $400 \mathrm{meq} / 100 \mathrm{~g}$ at $\mathrm{pH}=8$ (Custodio and Llamas 1983).

The precipitation of certain compounds has also been proven. An example is phosphates which, in the presence of calcium, precipitate in the first $60 \mathrm{~cm}$ of the vadose zone (Fig. 5).

Ion adsorption or fixation in the clay minerals, organic matter, or humic complexes affects various compounds, such as ammonium, organic compounds, phosphates and, to a lesser degree, boron, especially at the topmost level of the vadose zone, where the amount of clays and organic matter present is quite high.

Another process to be taken into consideration is the concentration due to evapotranspiration. This is note-

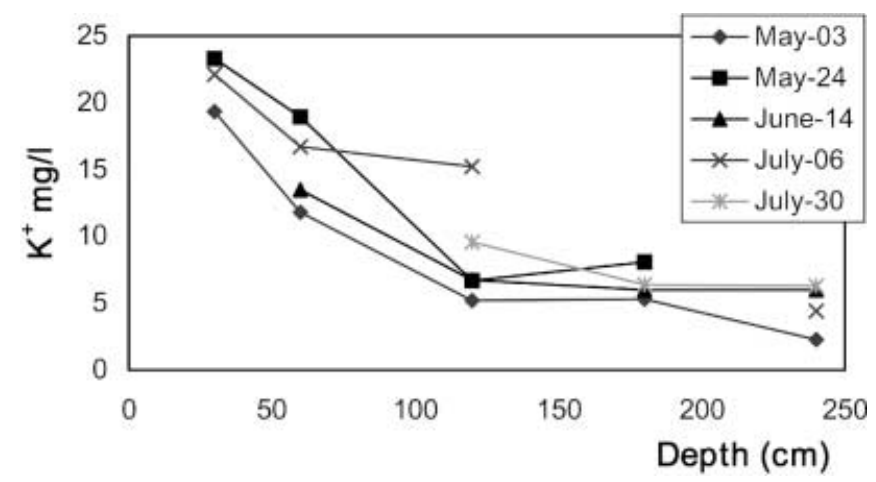

Fig. 4

Temporal evolution of the potassium concentrations in the vadose zone

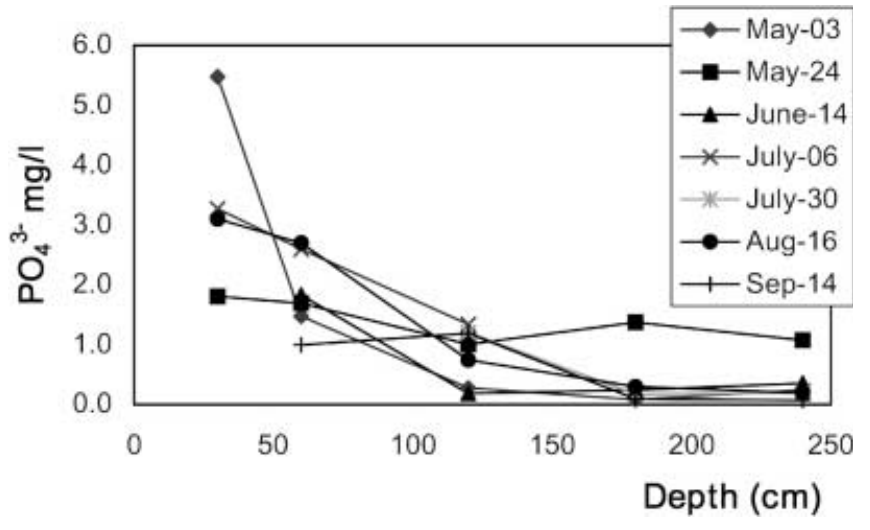

Fig. 5

Temporal evolution of the phosphate concentrations in the vadose zone

worthy in the first centimeters, especially in the summer months, giving rise to a concentration in salts, which is clearly shown in the values of conductivity and chlorides at the topmost level.

\section{Modeling results}

Modeling has only been applied to a certain number of the possible geochemical reactions produced in the vadose zone, as these reactions are of a very diverse nature and great complexity. This simplification limits the validity of the results obtained, but allows, at a first approximation, identification of some of the processes which take place in the vadose zone as well as establishing the magnitude of these reactions. The principal geochemical processes are represented by the reactions:

$\mathrm{CaCO}_{3}+\mathrm{H}_{2} \mathrm{CO}_{3} \leftrightarrow 2 \mathrm{Ca}^{2+}+2 \mathrm{HCO}_{3}^{-}$

Dissolution - precipitationofcalcite

$\mathrm{MgCa}\left(\mathrm{CO}_{3}\right)_{2}+\mathrm{H}_{2} \mathrm{CO}_{3} \leftrightarrow 2 \mathrm{Ca}^{2+}+2 \mathrm{Mg}^{2+}+2 \mathrm{HCO}_{3}^{-}$

Dissolution - precipitationofdolomite

$\mathrm{CaSO}_{4} \cdot 2 \mathrm{H}_{2} \mathrm{O} \leftrightarrow \mathrm{Ca}^{2+}+\mathrm{SO}_{4}^{2-}+2 \mathrm{H}_{2} \mathrm{O}$

Dissolution - precipitationofgypsum

$\mathrm{Ca}^{2+}+2 \mathrm{Na}$ (exchanged $) \leftrightarrow 2 \mathrm{Na}^{+}+\mathrm{Ca}$ (exchanged $)$

$\mathrm{Ca}^{2+}+2 \mathrm{~K}$ (exchanged) $\leftrightarrow 2 \mathrm{~K}^{+}+\mathrm{Ca}$ (exchanged)

$\mathrm{Mg}^{2+}+2 \mathrm{Na}$ (exchanged $) \leftrightarrow 2 \mathrm{Na}^{+}+\mathrm{Mg}$ (exchanged)

$\mathrm{Mg}^{2+}+2 \mathrm{~K}$ (exchanged) $\leftrightarrow 2 \mathrm{~K}^{+}+\mathrm{Mg}$ (exchanged)

where (exchanged) denotes cations exchanged on clays and/or organic matter.

The initial chemical data correspond to the results of the physico-chemical analyses carried out on samples of soil water collected in different samplings.

Mass transference calculations have been carried out between the points corresponding to the samplers installed at depths of 30 and $180 \mathrm{~cm}$ and those located at depths between 180 and $240 \mathrm{~cm}$. This discretization of the modeling has been carried out based on the results of the study of the evolution of physico-chemical parameters along the 
profile of the vadose zone, in which the evolutionary tendency of the majority of the parameters underwent a change starting at a depth of $180 \mathrm{~cm}$.

The results obtained from WATEQF have established that the soil water samples collected from different depths are seen to be oversaturated in calcite as well as dolomite, with saturation indices above 0.7 for calcite and 0.9 for dolomite. On the other hand, all of the samples were undersaturated in gypsum, with saturation indices between -0.4 and -0.8 (Table 3). The soil water is also oversaturated in hydroxiapatite, with indices of 7.89 at a depth of $30 \mathrm{~cm}$ (sampling March 1993). Calculation of these saturation indices implies certain errors, since the determination of $\mathrm{pH}$ as well as that of bicarbonate are carried out in the laboratory. In addition, a constant temperature has been assumed along the whole profile of the vadose zone.

The reactive models defined through NETPATH for the different samplings taken into consideration are very similar. As an example, in Table 4 the models obtained for capsules installed at depths of 30 and $180 \mathrm{~cm}$ are shown, corresponding to the sampling which took place on 30 November 1992. In this table, the chemical reactions considered as mass transference are defined.

The chemical reactions under consideration in model 1 are: precipitation of calcite, gypsum and dolomite dissolution, $\mathrm{CO}_{2}$ enrichment, and $\mathrm{Ca}^{2+}-\mathrm{Na}^{+}$and $\mathrm{Ca}^{2+}-\mathrm{K}^{+}$, with
$\mathrm{Na}^{+}$and $\mathrm{K}^{+}$fixing, respectively. Other models (models 2 and 3) take into consideration intervention of the $\mathrm{Mg}^{2+}$ ion in the ionic exchange reactions $\mathrm{Mg}^{2+}-\mathrm{Na}^{+}$and $\mathrm{Mg}^{2+}$ $\mathrm{K}^{+}$, since $\mathrm{K}^{+}$and/or $\mathrm{Na}^{+}$may replace exchangeable $\mathrm{Mg}^{2+}$. The application of these models to other samplings have provided similar results, although in some cases some of the proposed reactions have shown the complete opposite of what would have been expected. In the sampling of 16 September 1992 (Table 5), the reactive models define dolomite precipitation (model 1), and $\mathrm{K}^{+}$(model 2) or $\mathrm{Na}^{+}$ ion expulsion (model 3 ), but the amount of these reactions is minimal $(0.05 \mathrm{mmol} / \mathrm{l})$, and thus they may be considered as non-indicative.

The values for mass transference show that the more important processes are calcite precipitation, with maximum values of $3 \mathrm{mmol} / \mathrm{l}$, gypsum dissolution, with amounts between 1.1 and $1.9 \mathrm{mmol} / \mathrm{l}, \mathrm{Ca}^{2+}-\mathrm{Na}^{+}$ionic exchange, with values around $2 \mathrm{mmol} / \mathrm{l}$, and $\mathrm{CO}_{2}$ enrichment with values of $2 \mathrm{mmol} / \mathrm{l}$, which comes from oxidation of the organic matter present both in the soil as well as the treated wastewater used for irrigation. For the gypsum dissolution, this reaction not only refers to the dissolution of this substance, but also the sulfates present in the soil due to earlier fertilizations.

The models considered for the points corresponding to depths between 180 and $240 \mathrm{~cm}$ (samplings of September and November 1992) are shown in Table 6. It can

Table 3

Saturation indices of soil water samples for different depths in the vadose zone

\begin{tabular}{|c|c|c|c|c|c|c|}
\hline \multirow[t]{2}{*}{ Constituent } & \multicolumn{3}{|c|}{ September 1992 saturation indices } & \multicolumn{3}{|c|}{ November 1992 saturation indices } \\
\hline & $30 \mathrm{~cm}$ & $180 \mathrm{~cm}$ & $240 \mathrm{~cm}$ & $30 \mathrm{~cm}$ & $180 \mathrm{~cm}$ & $240 \mathrm{~cm}$ \\
\hline Calcite & 1.37 & 1.22 & 1.26 & 1.44 & 0.78 & 0.75 \\
\hline Dolomite & 2.27 & 1.92 & 2.01 & 2.46 & 1.08 & 0.98 \\
\hline Gypsum & -0.73 & -0.58 & -0.48 & -0.72 & -0.53 & -0.51 \\
\hline
\end{tabular}

Table 4

NETPATH modeling results for sampling of 30 November 1992 and depth interval 30-180 cm

Model 1

Precipitation of calcite

Dissolution of gypsum

Dissolution of dolomite

Enrichment of $\mathrm{CO}_{2}$

$\mathrm{Ca}^{2+}-\mathrm{Na}^{+}$

$\mathrm{Ca}^{2+}-\mathrm{K}^{+}$

\begin{tabular}{lr} 
Model 2 & \\
\hline Precipitation of calcite & -3.479 \\
Dissolution of gypsum & +1.903 \\
Enrichment of $\mathrm{CO}_{2}$ & +2.010 \\
$\mathrm{Ca}^{2+}-\mathrm{Na}^{+}$ & -2.254 \\
$\mathrm{Ca}^{2+}-\mathrm{K}^{+}$ & -0.045 \\
$\mathrm{Mg}^{2+}-\mathrm{K}^{+}$ & -0.144
\end{tabular}

\section{Model 3}

Precipitation of calcite

Dissolution of gypsum

Enrichment of $\mathrm{CO}_{2}$

$\mathrm{Ca}^{2+}-\mathrm{Na}^{+}$

$\mathrm{Ca}^{2+}-\mathrm{K}^{+}$

$\mathrm{Mg}^{2+}-\mathrm{Na}^{+}$
$-3.479$

$+1.903$

$+2.009$

$-2.110$

$-0.189$

$-0.144$

Table 5

NETPATH modeling results for sampling of 16 September 1992 and depth interval 30-180 cm

\begin{tabular}{|c|c|c|c|c|c|}
\hline \multicolumn{2}{|l|}{ Model 1} & \multicolumn{2}{|l|}{ Model 2} & \multicolumn{2}{|l|}{ Model 3} \\
\hline $\begin{array}{l}\text { Precipitation of } \\
\text { calcite }\end{array}$ & -3.021 & $\begin{array}{l}\text { Precipitation of } \\
\text { calcite }\end{array}$ & -3.133 & $\begin{array}{l}\text { Precipitation of } \\
\text { calcite }\end{array}$ & -3.133 \\
\hline Dissolution of gypsum & +1.127 & Dissolution of gypsum & +1.127 & Dissolution of gypsum & +1.127 \\
\hline Precipitation dolomite & -0.056 & Enrichment of $\mathrm{CO}_{2}$ & +3.287 & Enrichment of $\mathrm{CO}_{2}$ & +3.287 \\
\hline Enrichment of $\mathrm{CO}_{2}$ & +3.287 & $\mathrm{Ca}^{2+}-\mathrm{Na}^{+}$ & -2.297 & $\mathrm{Ca}^{2+}-\mathrm{Na}^{+}$ & -2.353 \\
\hline $\mathrm{Ca}^{2+}-\mathrm{Na}^{+}$ & -2.297 & $\mathrm{Ca}^{2+}-\mathrm{K}^{+}$ & -0.339 & $\mathrm{Ca}^{2+}-\mathrm{K}^{+}$ & -0.283 \\
\hline $\mathrm{Ca}^{2+}-\mathrm{K}^{+}$ & -0.283 & $\mathrm{Mg}^{2+}-\mathrm{K}^{+}$ & +0.056 & $\mathrm{Mg}^{2+}-\mathrm{Na}^{+}$ & +0.056 \\
\hline
\end{tabular}


Table 6

NETPATH modeling results for sampling of 16 September and 30 November 1992 and depth interval 180-240 cm

\begin{tabular}{|c|c|c|c|}
\hline \multicolumn{2}{|c|}{16 September 1992} & \multicolumn{2}{|c|}{30 November 1992} \\
\hline $\begin{array}{l}\text { Precipitation } \\
\text { of calcite }\end{array}$ & -3.905 & $\begin{array}{l}\text { Precipitation } \\
\text { of calcite }\end{array}$ & -0.683 \\
\hline $\begin{array}{l}\text { Dissolution } \\
\text { of gypsum }\end{array}$ & +1.903 & $\begin{array}{l}\text { Dissolution } \\
\text { of gypsum }\end{array}$ & +0.085 \\
\hline $\begin{array}{l}\text { Dissolution } \\
\text { of dolomite }\end{array}$ & +2.010 & $\begin{array}{l}\text { Dissolution } \\
\text { of dolomite }\end{array}$ & +1.553 \\
\hline $\begin{array}{l}\text { Enrichment } \\
\text { of } \mathrm{CO}_{2}\end{array}$ & +0.009 & Loss of $\mathrm{CO}_{2}$ & -1.905 \\
\hline $\mathrm{Ca}^{2+}-\mathrm{K}^{+}$ & +0.012 & $\mathrm{Ca}^{2+}-\mathrm{K}^{+}$ & -0.001 \\
\hline $\mathrm{Mg}^{2+}-\mathrm{Na}^{+}$ & +2.004 & $\mathrm{Mg}^{2+}-\mathrm{Na}^{+}$ & +1.503 \\
\hline
\end{tabular}

be seen that some of the chemical reactions differ from those proposed previously. In this case, the model defines calcite precipitation, dolomite and gypsum dissolution, $\mathrm{Ca}^{2+}-\mathrm{Na}^{+}$exchange, with expulsion of sodium, and impoverishment of $\mathrm{CO}_{2}$ (the enrichment of the September sampling is not indicative, $0.009 \mathrm{mmol} / \mathrm{l}$ ). The quantification of these reactions shows that the values obtained differ greatly according to the samplings. This demonstrates that the intensity of these reactions is variable according to the time in action of diverse factors (such as $\mathrm{pH}$ ) that condition these reactions.

The reactions described here are a consequence of the existing conditions in this depth interval. This level falls within the capillary fringe and, thus, may produce a mixing process between the infiltrated water and groundwater that gives rise to the reactions described above, as well as stricter aerobic conditions.

The mass transference values obtained in these reactive models for the different depth intervals are approximated because the majority of elements, in addition to intervening in the reactions described above, also participate in others. A good example is the calcium ion, which, in addition to being implicated in some of the processes described here, also comes into play in phosphate precipitation and $\mathrm{Ca}^{2+}-\mathrm{NH}_{4}{ }^{+}$exchange reactions.

It may be supposed that some of the reactions described above vary with time, as there is a whole series of factors that affect them, such as temperature variation, composition of the irrigation water, contributions from other substances (e.g., fertilizers), infiltration of rain water, etc. The amount of reactants or reaction products also varies, which can be proven if the values obtained for each of the reactions in the different samplings are compared.

\section{Conclusions}

1. During percolation throughout the vadose zone of treated wastewater used for irrigation, a whole series of physical, chemical, and biological processes are produced, which result in the treatment of infiltrated water.
2. The purification treatment process is reflected in the decreased values of certain parameters such as $\mathrm{BOD}_{5}$, COD, potassium, phosphates, ammonium, and nitrites along the profile of the vadose zone.

3. The processes which give rise to this purification treatment and the modification of concentrations of the different chemical compounds are of a very diverse nature; the most important are ionic exchange, nitrification, biodegradation, and precipitation.

4. The results obtained with the hydrogeochemical NETPATH model agree with those obtained experimentally. Precipitation of calcite, enrichment of $\mathrm{CO}_{2}$, ionic exchange between cations with $\mathrm{K}^{2+}$, and $\mathrm{Na}^{+}$fixing have been proven, as well as gypsum dissolution between depths of 30 and $180 \mathrm{~cm}$. In contrast, in the next modeled interval, between depths of 180 and $240 \mathrm{~cm}$, release of $\mathrm{Na}^{+}$and impoverishment of $\mathrm{CO}_{2}$ have been shown.

5. The application of hydrogeochemical models, such as NETPATH, in studies on vadose zones permits verification of the physico-chemical reactions that are deduced from the experimental data, as well as their quantification, making it possible to establish the importance of each one of these processes.

\section{References}

APHA AWWA WPCF (1995) Standard methods for the examination of water and wastewater, 19th edn. Washington, DC

Appelo CAJ, Willemsen A, Beekman HE, Griffioen J (1990) Geochemical calculations and observations on salt water intrusions. II. Validation of a geochemical model with laboratory experiments. J Hydrol 120:225-250

Azevedo AS, Kanwar RS, Singh P, Ahuja L, Pereira LS (1997) Simulating atrazine transport using root zone water quality model for Iowa soil profiles. J Environ Qual 26:153-164

Beltran J, Hernandez F, Morell I, Navarrete P, Aroca E (1993) Analysis of several pesticides along the unsaturated zone in an experimental citrus grove of Castellon, Spain. Sci Total Environ 132:243-257

Beltran J, Hernandez F, Lopez FJ, Morell I (1995) Study of sorption processes of selected pesticides on soils and ceramic porous cups used for soil solution sampling. Int J Environ Anal Chem 58:287-303

Boulding JR (1995) Practical handbook of soil, vadose zone and ground water contamination. Assessment, prevention and remediation. Lewis Publishers, Boca Raton

Bustamante I (1990) Land application: its effectiveness in purification of urban and industrial wastewaters in La Mancha, Spain. Environ Geol 16(3):179-185

Clark JW (1959) New method for biochemical oxygen demand. Eng Exp Station, New Mexico State University. Bulletin 11a

Custodio E, Llamas MR (1983) Hidrología Subterránea, 2nd edn. Editorial Omega, Barcelona

Esteller MV, Morell I (1993) Irrigation with treated wastewater and its effect on the Castellon Plain Aquifer (Spain). In: Nath B, Candela L, Hens L, Robison JP (eds) Environmental pollution. European Center for Pollution Research, London, vol. I, pp 246253

Esteller MV, Morell I, Durán A, García-Agustín P, Lapeña L (1994) Experimental citrus irrigation with reclaimed wastewater on a Spanish coastal aquifer. In: Reeve C, Watts J (eds). 
Groundwater: drought, pollution and management. Balkema, Rotterdam, pp 55-63

Flores I, Blas G, Hernández G, Alcalá R (1997) Distribution and sequential extraction of some heavy metals from soil irrigated with wastewater from Mexico City. Water Air Soil Pollut 98(1/ 2):105-117

Gerritse RG, Beltrán J, Hernández F (1996) Adsorption of atrazine, simazine and glyphosate in soils of the Gnangara Mound, Western Australia. Aust J Soil Res 34:599-607

Gómez de Barrera D, Gamón M, Lorenzo E, Saez A (1993) Residual herbicide movement in soil columns. Sci Total Environ 132:155-165

Jabro JD, Toth JD, Dou Z, Fox RH, Fritton DD (1995) Evaluating of nitrogen version of LEACHM for predicting nitrate leaching. Soil Sci 160(3):209-217

Jemison JM, Fox RH (1994) Nitrate leaching from nitrogen-fertilized and manured corn measured with zero-tension pan lysimeters. J Environ Qual 23:337-343

López FJ, Giménez E, Hernández F (1993) Analytical study on the determination of boron in environmental water samples.

Fresenius J Anal Chem 346:984-987

Moreau C, Mouvet C (1997) Sorption and desorption of atrazine, dethylatrazine and hidroxyatrazine by soil and aquifer solids. J Environ Qual 26:416-424

Morell I, Padilla F, Alberto JM (1996) Modelling of leaching of chloride and nitrogen species in an experimental citrus grove. Ecol Model 87:235-247
Plummer LN, Jones BF, Truesdell AH (1984) WATEQF, a FORTRAN IV version of WATEQ, a computer program for calculating chemical equilibrium of natural waters. US Geological Survey Water Resources Investigations Report 76-13

Plummer LN, Prestemon EC, Parkhurst DL (1991) An interactive code (NETPATH) for modeling net geochemical reactions along a flow path. US Geological Survey Water Resources Investigations Report 91-4078

Ramachandran V, D'Souza TJ (1997) Extractable zinc and manganese as related to applied cadmium in contrasting Indian soil. Chem Spec Bioavail 9(4):131-143

Salgot M, Pascual MA (1991) Irrigation with treated wastewater: recycling, recovery and treatment of nutrients. In: Mujeriego R, Asano T (eds) Proc Int Symp Wastewater Reclamation and Reuse, Gerona, Spain, pp 83-92

Shahalam A, Abu Zahra BM, Jaradat A (1998) Wastewater irrigation effect on soil, crop and environment: a pilot scale study at Irbid, Jordan. Water Air Soil Pollut 106(3/4):425-445

Tedaldi DJ, Loehr R (1992) Effects of wastewater irrigation on aqueous geochemistry near Paris, Texas. Ground Water 30(5):709-719

Truesdell AH, Jones BF (1974) WATEQ, a computer program for calculating chemical equilibria of natural waters. J Res US Geol Surv 2:1233-1248

Wilson LG, Everett LG, Cullen, SJ (1995) Handbook of vadose zone characterization and monitoring. Lewis Publishers, Boca Raton 